\title{
Study of BMI in pregnancy and its correlation with maternal and perinatal outcome
}

\author{
Jaya Choudhary, Swati Singh*, Kalpana Tiwari
}

Department of Obstetrics and Gynecology, Mahatma Gandhi Medical College and Hospital, Sitapur, Jaipur, India

Received: 13 April 2018

Accepted: 05 May 2018

\section{*Correspondence:}

Dr. Swati Singh,

E-mail: drswatisingh1188@gmail.com

Copyright: () the author(s), publisher and licensee Medip Academy. This is an open-access article distributed under the terms of the Creative Commons Attribution Non-Commercial License, which permits unrestricted non-commercial use, distribution, and reproduction in any medium, provided the original work is properly cited.

\begin{abstract}
Background: Maternal nutrition plays an important role in maternal and fetal outcome. The low maternal BMI or Obesity is associated with adverse outcome.

Methods: A total 148 primigravida included. BMI was calculated on first visit and in each trimester, all booked patient was followed throughout pregnancy and delivery for any maternal and fetal complications.

Results: $(66.2 \%)$ of patients were with normal BMI, $(17.56 \%)$ were underweight, $(10.13 \%)$ were overweight and $(6.08 \%)$ patients were obese. APH was seen in $(11.1 \%)$ and $(6.7 \%)$ cases in BMI grades 'IV and III' respectively. PIH was present in total 10 cases, $(33.3 \%)$ cases belonged to BMI grades IV. Anemia was present in total 51 cases $(53.8 \%)$ belonged to BMI grade I. Preterm delivery was present in total 5 cases and out of them $(7.7 \%),(2 \%)$ and $(11.1 \%)$ belonged to BMI grades I, II and IV respectively. GDM was present in 11 cases and out of them $(26.7 \%)$ and $(44.4 \%)$ cases belonged to BMI grade III and IV respectively. PPH was present in total 5 cases and out of them (7.7\%), (2\%) and (11.1\%) belonged to BMI grades I, II and IV respectively. In BMI grade I group, (96.2\%) babies had birth weight $<2.5$, while in BMI grade IV, $(88.9 \%)$ babies had birth weight $>2.5(22.2 \%)$ cases of fetal macrosomia belonged to BMI grade IV.

Conclusions: There is importance of pr-pregnancy counseling in maintaining weight of women during pregnancy to avoid pregnancy maternal and fetal outcomes.
\end{abstract}

Keywords: BMI, Maternal and fetal outcomes, Maternal nutrition

\section{INTRODUCTION}

Obesity is defined as abnormal growth of adipose tissue due to an enlargement of fat cell size (hypertrophic obesity) or an increase in fat cell number (hyper plastic obesity). ${ }^{1)}$

According to the WHO, obesity is one of the most common and most neglected public health problems in both developing and developed countries. ${ }^{2}$ Globally 1 out of 6 adults is obese, Due to obesity nearly 2.8 million individuals die each year. ${ }^{3}$ India, is having the second highest population overload in the world and malnutrition due to poverty which dominated in the previous years, is being rapidly transisted by obesity associated with affluence. $^{4}$

Studies from different parts of India have provided evidence of the rising prevalence of obesity. ${ }^{5-7}$ There is increase in obesity in Indian women from $10.6 \%$ to $14.8 \%$ during last decade in urban areas at the same time in rural area, $48.2 \%$ of pre-pregnant women are underweight. $^{8,9}$

There are various markers used to diagnose obesity like Body Mass Index (BMI), waist circumference, 
calculation of waist to hip circumference, measuring the thickness of skin fold, techniques such as ultrasound and biochemical markers like total cholesterol, triglyceride, low density lipoproteins, high density lipoproteins etc. BMI involves two factors i.e height and weight, irrespective of age, gender, race, family history or sex. It is calculated by dividing a person's body weight in kilograms by their height in meters squared (weight $[\mathrm{kg}]$ height $[\mathrm{m}]^{2}$ ) as shown below

[Weight $(\mathrm{kg}) \div$ height $\left.\left(\mathrm{m}^{2}\right)\right]=$ BMI"

The BMI cutoffs are:

- Below 18.5 Underweight

- 18.6-24.9 Normal weight

- 25.0-29.9 Overweight

- 30 and greater Obese

- 40 and greater Morbid or extreme obesity

The risk for obesity related obstetric complications appear to start from a BMI of about $21 \mathrm{~kg} / \mathrm{m}^{2}$. Obese and overweight females undergoing pregnancy and child birth as calculated by maternal BMI will have higher risk for significant antenatal, postpartum and neonatal complications. Diabetes, hypertensive disorders including preeclampsia, post date pregnancies, caesarean sections, macrosomia, thromboembolism, fetal deaths have all been associated with maternal obesity. ${ }^{10-13}$ There is linear relationship between maternal obesity and fetal macrosomia. ${ }^{14}$ The women who are overweight and obese have more chances to require a caesarean section for delivery..$^{15,16}$

Maternal malnutrition is the most important underlying determinant factor in adverse maternal and fetal outcome A malnourished mother gives birth to undernourished infant who struggle to thrive. The low maternal BMI is associated with increased risk of abortion and intrauterine growth restriction anemia, which may further cause low Apgar scores and increased early neonatal deaths. ${ }^{17,18}$

As maternal nutrition and weight gain during pregnancy are modifiable factors, so the knowledge of association between maternal weight gain during pregnancy, obstetric complications and fetal outcomes becomes essential. The objectives of the study was to find out the early pregnancy BMI, prevalence of different level of BMI and the correlation to assess the effect of low weight, over weight and obesity on maternal and fetal outcome, compared to those of normal weight women.

\section{METHODS}

This is a Prospective study conducted in the Department of Obstetrics and Gynecology, Mahatma Gandhi Medical College and Hospital, Sitapura, Jaipur after getting permission from ethical committee from September 2016 to September 2017.

\section{Inclusion criteria}

- $\quad$ Singleton pregnancy

- Primigravida

- $\quad$ Booked patients.

\section{Exclusion criteria}

- Patients not giving consent.

- Multifetal gestation

- Patient with known medical complication like diabetes mellitus, cardiac disease hypertension, chronic renal disease and endocrinal dysfunctions, pre-eclampsia, eclampsia, gestational diabetes mellitus and ASA>GRADE 2.

nformed consent was taken from all the patients who had participated in the study. A total number of 148 cases who attended antenatal checkup outpatient Department of MGMC were taken. All the cases were primigravida and booked patient in first trimester. They were selected based on inclusion and exclusion criteria.

BMI was calculated by measuring height and weight ratio on first visit and in each trimester, all booked patient in study group were followed throughout pregnancy and delivery for any maternal and fetal complications. Maternal and perinatal variables were also noted.

\section{Maternal outcome variable}

- Pregnancy induced hypertension

- Mode of Delivery- cesarean, instrumentation (ventouse, forceps etc.), normal vaginal delivery

- Preterm and Posterm delivery

- Gestational diabetes mellitus

\section{Perinatal Outcome variable}

- Low Birth Weight

- $\quad$ APGAR score at 1 and 5 minute

- Admission to NICU

- Macrosomia

\section{Valuation parameter}

- Patients were categorized according to first trimester BMI.

- It was calculated by using formula = (weight in kilograms/height in meters ${ }^{2}$ )

The BMI cutoffs are

- Below 18.5 Underweight

- 18.6-24.9 Normal weight

- 25.0-29.9 Overweight

- 30 and greater Obese

- 40 and greater Morbid or extreme obesity. 


\section{RESULTS}

Table 1 shows distribution of cases according to age. Most of the patients age group were 21-25 years (48.6\%) followed by $26-30$ years $(26.4 \%), 18-20$ years $(21.6 \%)$ while only $3.4 \%$ cases were in the age group $>30$ year. Similar observation were found by John et al where only $4 \%$ females were in age group $<24$ years, $58 \%$ in $25-30$ years, $38 \%$ in $31-35$ years. ${ }^{19}$

Table 1: Distribution of cases according to age group.

\begin{tabular}{|lll|}
\hline Age group (years) & No. of cases & Percentage \\
\hline $18-20$ & 32 & 21.6 \\
\hline $21-25$ & 72 & 48.6 \\
\hline $26-30$ & 39 & 26.4 \\
\hline$>30$ & 5 & 3.4 \\
\hline Total & 148 & 100 \\
\hline Mean age & $24.00 \pm 3.60$ & \\
\hline
\end{tabular}

Table 2: Distribution of cases according to occupation.

\begin{tabular}{|lll|}
\hline Occupation & No. of cases & Percentage \\
\hline House wife & 70 & 47.3 \\
\hline Laborer & 64 & 45.9 \\
\hline Sedentary & 14 & 6.8 \\
\hline Total & 148 & 100 \\
\hline
\end{tabular}

In present study, maximum number of cases $47.3 \%$ were housewives, $45.9 \%$ cases were laborer and $6.8 \%$ cases were sedentary. In present study, no patients were of socioeconomic status of grade I, while only $3.4 \%$ patients were socioeconomic status II. $35.8 \%, 37.8 \%$ and $23 \%$ patients had their socioeconomic status III, IV and V respectively. Similar results were observed by John et al where they found $0 \%, 2 \%, 30 \%, 36 \%$ and $32 \%$ patients in socioeconomic status I, II, III, IV and V respectively*. 19

Table 3: Distribution of cases according to socioeconomic status.

\begin{tabular}{|lll|}
\hline Socioeconomic status & No. of cases & Percentage \\
\hline I & 0 & - \\
\hline II & 5 & 3.4 \\
\hline III & 53 & 35.8 \\
\hline IV & 56 & 37.8 \\
\hline V & 34 & 23.0 \\
\hline Total & 148 & 100 \\
\hline
\end{tabular}

Table 4: No. of cases according to BMI group.

\begin{tabular}{|ll|}
\hline BMI Group & No. of cases $(\%)$ \\
\hline I $(\leq 18.5)$ & $26(17.56 \%)$ \\
\hline II $(18.51-24.99)$ & $98(66.2 \%)$ \\
\hline III $(25-29.99)$ & $15(10.13 \%)$ \\
\hline IV $(\geq 30)$. & $09(6.08 \%)$ \\
\hline Total & 148 \\
\hline
\end{tabular}

Table 4 shows distribution of cases according to BMI group. 26 cases were in group I $(\leq 18.5) .98$ cases were in group II (18.51-24.99). 15 cases were in group III (25$29.99)$ and 9 cases were in group IV $(\geq 30)$. In the study conducted by Tharihalli et al, in which $15 \%$ cases were underweight, $68 \%$ were normal, $12 \%$ were overweight and $5 \%$ were obese. ${ }^{20}$ Majority of the cases were from normal BMI group followed by underweight patients. The probable reason being most of the patients coming to our hospital were from lower and lower middle class. In western countries $28 \%$ women are overweight and $11 \%$ are in obese category, according to RCOG. ${ }^{21}$

Table 5: Distribution of Cases according to maternal outcome in relation to $\mathrm{BMI}\left(\mathrm{kg} / \mathrm{m}^{2}\right)$.

\begin{tabular}{|c|c|c|c|c|c|c|c|c|c|c|c|}
\hline \multirow{3}{*}{$\begin{array}{l}\text { Maternal } \\
\text { outcome }\end{array}$} & \multirow{3}{*}{ Total } & \multicolumn{8}{|c|}{ BMI Group $\left(\mathrm{kg} / \mathrm{m}^{2}\right)$ first time presentation } & \multirow{3}{*}{$\chi^{2}$} & \multirow{3}{*}{$\mathbf{p}$} \\
\hline & & \multicolumn{2}{|c|}{$\leq 18.5(n=26)$} & \multicolumn{2}{|c|}{ 18.51-24.99 $(n=98)$} & \multicolumn{2}{|c|}{$25.00-29.00(n=15)$} & \multicolumn{2}{|c|}{$\geq \mathbf{3 0}(\mathrm{n}=\mathbf{9})$} & & \\
\hline & & $\overline{\text { No. }}$ & $\%$ & No. & $\%$ & No. & $\%$ & $\bar{N}$ No. & $\%$ & & \\
\hline APH & 2 & 0 & - & 0 & - & 1 & 6.7 & 1 & 11.1 & 11.308 & 0.010 \\
\hline $\mathrm{PIH}$ & 10 & 1 & 3.8 & 4 & 4.1 & 2 & 13.3 & 3 & 33.3 & 12.582 & 0.006 \\
\hline Anaemia & 51 & 14 & 53.8 & 36 & 36.7 & 1 & 6.7 & 0 & - & 14.414 & 0.002 \\
\hline Pre term & 5 & 2 & 7.7 & 2 & 2.0 & 0 & - & 1 & 11.1 & 4.193 & 0.241 \\
\hline GDM & 11 & 0 & - & 3 & 3.1 & 4 & 26.7 & 4 & 44.4 & 30.795 & $<0.001$ \\
\hline IUGR & 15 & 8 & 30.8 & 5 & 5.1 & 0 & - & 2 & 22.2 & 18.015 & $<0.001$ \\
\hline PPH & 5 & 2 & 7.7 & 2 & 2.0 & 0 & - & 1 & 11.1 & 4.193 & 0.241 \\
\hline Other & 4 & 1 & 3.8 & 3 & 3.1 & 0 & - & 0 & - & 0.844 & 0.839 \\
\hline
\end{tabular}

According to maternal outcome in relation to BMI out of 2 cases of APH, $6.7 \%$ and $11.1 \%$ cases were in over weight and obese group respectively and the difference was found statistically significant $(\mathrm{p}<0.05)$. PIH was present in total 10 cases and out of them $1(3.8 \%), 4$
(4.1\%), $2(13.3 \%)$ and $3(33.3 \%)$ cases belonged to underweight, normal, over weight and obese BMI group in this study, incidence of PIH is significantly associated with increasing maternal obesity, similar findings were reported by Tharihalli and Thathagari. ${ }^{22}$ Obesity is known 
as one important risk factor for pregnancy related hypertension and preeclampsia. Frederick et al found that every $1 \mathrm{~kg} / \mathrm{m}^{2}$ increase in prepregnancy BMI resulted in an $8 \%$ increased risk of preeclampsia (adjusted $\mathrm{RR}=$ 1.08; $\mathrm{CI}=1.05-1.11) .{ }^{23}$ Anemia was present in 51 cases and out of them $14(53.8 \%), 36(36.7 \%)$ and $1(6.7 \%)$ cases of underweight, normal weight and overweight group, Preterm delivery was present in total 5 cases and out of them $2(7.7 \%), 2(2 \%)$ and $1(11.1 \%)$ belonged to underweight, normal weight and obese BMI group.

Table 6: Distribution of cases according to type of Delivery and maternal BMI.

\begin{tabular}{|lllll|}
\hline BMI & \multicolumn{2}{l}{ Vaginal delivery } & LSCS & \\
group & No. $(\%)$ & $\begin{array}{l}\text { Mean } \\
\text { BW }\end{array}$ & No. $(\%)$ & $\begin{array}{l}\text { Mean } \\
\text { BW }\end{array}$ \\
\hline$\leq 18.5$ & $21(22.3)$ & 1.44 & $5(9.3)$ & 1.66 \\
\hline $\begin{array}{l}18.51- \\
24.99\end{array}$ & $67(71.3)$ & 2.77 & $31(57.4)$ & 2.82 \\
\hline $\begin{array}{l}25.00- \\
29.99\end{array}$ & $5(5.3)$ & 3.05 & $10(18.5)$ & 3.11 \\
\hline $\begin{array}{l}30.00- \\
39.99\end{array}$ & $1(1.1)$ & 2.20 & $8(14.8)$ & 3.20 \\
\hline Total & $\begin{array}{l}94 \\
(63.51 \%)\end{array}$ & & $\begin{array}{l}54 \\
(36.48 \%)\end{array}$ \\
\hline
\end{tabular}

GDM was present in 11 cases and out of them $3(3.1 \%)$, $4(26.7 \%)$ and $4(44.4 \%)$ cases belonged to normal, over and obese BMI group respectively, this shows that maternal obesity is directly linked to gestational diabetes mellitus. IUGR was present in 15 cases and out of them 8 $(30.8 \%), 5(5.1 \%)$ and $2(22.2 \%)$ belonged to underweight, normal weight and obese BMI group respectively, this shows that maternal nutritional status is directly linked to the nutrional status of fetus. PPH was present in total 5 cases and out of them 2 (7.7\%), 2 (2\%) and $1(11.1 \%)$ cases belonged to underweight, normal weight and obese BMI group respectively while other maternal outcome was present in 4 cases and out of them $1(3.8 \%)$ and $3(3.1 \%)$ belonged to underweight and normal weight BMI group. On applying Chi square test, APH, PIH, Anemia had significant relation $(\mathrm{p}<0.05)$ while GDM and Hypertension had highly significant difference $(\mathrm{p}<0.001)$ and preterm, PPH and other had insignificant difference $(\mathrm{p}>0.05)$.

According to type of delivery (22.3\%) 21 cases of vaginal had their BMI underweight group and their mean birth weight was $1.44 \mathrm{~kg}, 67$ cases had their BMI within normal range and their mean birth weight was $2.77 \mathrm{~kg}, 5$ cases had their BMI within over weight range and their mean birth weight was $3.05 \mathrm{~kg}$ while only 1 case $(1.1 \%)$ had her BMI in obese group and the baby birth weight was $2.20 \mathrm{~kg}$. This shows as BMI increases baby birth weight increases but chances of vaginal delivery decreases. In caesarean deliveries, this trend also found where in underweight BMI group mean baby birth weight was $1.66 \mathrm{~kg}$ in normal BMI group, mean baby birth weight was $2.82 \mathrm{~kg}$, in overweight BMI group mean birth weight was $3.11 \mathrm{~kg}$ and in obese BMI group, mean birth weight was $3.20 \mathrm{~kg}$.

In LSCS group, 5, 31, 10 and 8 cases had their BMI under weight, normal weight, over weight and obese group respectively and their mean birth weights were $1.66 \mathrm{~kg}, 2.82 \mathrm{~kg}, 3.11 \mathrm{~kg}$ and $3.20 \mathrm{~kg}$ respectively. In this study, we also found that maternal higher pre-pregnancy BMI and excessive GWG were associated with caesarean delivery. This may be that large size baby birth could cause delivery complications, such as caesarean delivery. This study observed that highest number of women has undergone caesarean section in obese group (8 out of 9 ). This correlates with the study conducted by Cedergren $\mathrm{M}^{24}$

Table 7: Distribution of cases according to APGAR score in relation to BMI.

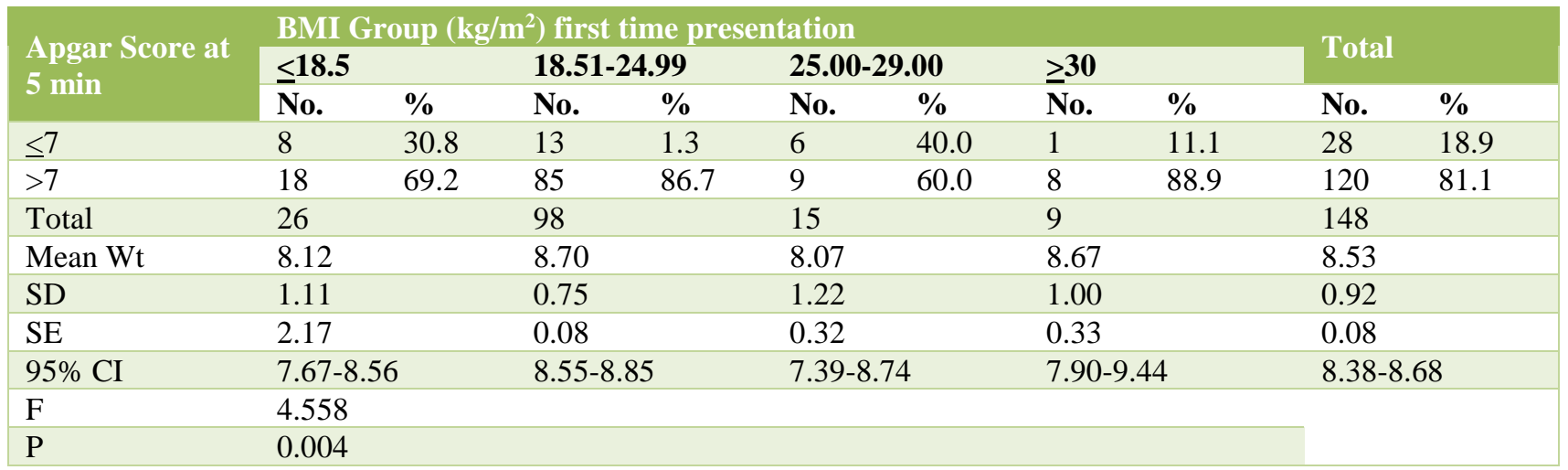

According to Apgar score at 5 minutes, $30.8 \%$ and $69.2 \%$ cases of underweight group had their Apgar score $\leq 7$ and
$>7$ respectively, in normal weight group, $1.3 \%$ and $86.7 \%$ cases had their Apgar score $\leq 7$ and $>7$ respectively, in 
over weight group, $40 \%$ and $60 \%$ cases had their Apgar score $\leq 7$ and $>7$ respectively while in obese cases, $11.1 \%$ and $88.9 \%$ cases had their Apgar score $\leq 7$ and $>7$ respectively.
On applying ANOVA test, the difference was found statistically significant $(\mathrm{p}<0.01)$.

Table 8: Distribution of cases according to birth weight in relation to BMI.

\begin{tabular}{|c|c|c|c|c|c|c|c|c|c|c|}
\hline \multirow{3}{*}{ Birth weight } & \multicolumn{8}{|c|}{ BMI Group $\left(\mathrm{kg} / \mathrm{m}^{2}\right)$ first time presentation } & \multirow{2}{*}{\multicolumn{2}{|c|}{ Total }} \\
\hline & \multicolumn{2}{|c|}{$\leq 18.5$} & \multicolumn{2}{|c|}{ 18.51-24.99 } & \multicolumn{2}{|c|}{$25.00-29.00$} & \multicolumn{2}{|l|}{$\geq \mathbf{3 0}$} & & \\
\hline & $\bar{N}$ No. & $\%$ & No. & $\%$ & No. & $\%$ & No. & $\%$ & No. & $\%$ \\
\hline$\leq 2.5$ & 25 & 96.2 & 26 & 26.5 & 2 & 13.3 & 1 & 11.1 & 54 & 36.5 \\
\hline$>2.5$ & 1 & 3.8 & 72 & 73.5 & 13 & 86.7 & 8 & 88.9 & 94 & 63.5 \\
\hline Total & 26 & & 98 & & 15 & & 9 & & 148 & \\
\hline Mean Wt & 1.48 & & 2.79 & & 3.09 & & 3.10 & & 2.61 & \\
\hline SD & 0.61 & & 0.54 & & 0.51 & & 0.56 & & 0.76 & \\
\hline SE & 0.12 & & 0.05 & & 0.13 & & 0.19 & & 0.06 & \\
\hline $95 \% \mathrm{CI}$ & 1.24 & & 2.68 & & 2.81 & & 2.67 & & 2.48 & \\
\hline $\mathrm{F}$ & 45.2 & & & & & & & & & \\
\hline $\mathrm{P}$ & $<0.0$ & & & & & & & & & \\
\hline
\end{tabular}

In present study, in under weight BMI group, $96.2 \%$ and $3.8 \%$ babies had their birth weight $\leq 2.5$ and $>2.5 \mathrm{~kg}$, in normal BMI group, $26.5 \%$ and $73.5 \%$ babies had their birth weight $\leq 2.5$ and $>2.5 \mathrm{~kg}$, in over weight patients, $13.3 \%$ and $86.7 \%$ babies had their birth weight $\leq 2.5$ and $>2.5 \mathrm{~kg}$ while in obese group, $11.1 \%$ and $88.9 \%$ babies had their birth weight $\leq 2.5$ and $>2.5 \mathrm{~kg}$ respectively and this difference was found statistically highly significant $(\mathrm{p}<0.001)$.

Table 9 shows correlation between mean baby birth weight $(\mathrm{kg})$ and mean maternal BMI. Only underweight BMI group had significant changes where $r=0.600$ $(\mathrm{p}=0.001)$ while all other group like normal, heavy weight and obese group had insignificant difference.

According to above table, macrosomia was present in only 7 cases and out of them 3,2 and 2 cases belonged to BMI grade II, III and IV respectively and the difference was found statistically significant $(\mathrm{p}<0.05)$, Tharihalli and Thathagari found in their study out of 500 cases Macrosomia was seen in (32\%) obese group followed by overweight group (16\%). ${ }^{22}$

Table 9: Correlation between mean baby birth weight (kg) and mean maternal BMI.

\begin{tabular}{|c|c|c|c|c|c|c|}
\hline \multirow{2}{*}{$\begin{array}{l}\text { BMI } \\
\text { Group }\end{array}$} & \multicolumn{2}{|c|}{$\begin{array}{l}\text { Birth } \\
\text { Weight }\end{array}$} & \multicolumn{2}{|l|}{ BMI } & \multirow[t]{2}{*}{$\mathbf{r}$} & \multirow[t]{2}{*}{$\mathbf{P}$} \\
\hline & Mean & SD & Mean & SD & & \\
\hline$\leq 18.5$ & 1.48 & 0.61 & 14.82 & 0.88 & 0.600 & 0.001 \\
\hline $\begin{array}{l}18.51- \\
24.99\end{array}$ & 2.79 & 0.54 & 22.16 & 1.65 & 0.167 & 0.100 \\
\hline $\begin{array}{l}25.00- \\
29.99\end{array}$ & 3.09 & 0.51 & 27.10 & 1.95 & 0.052 & 0.853 \\
\hline $\begin{array}{l}30.00- \\
39.99\end{array}$ & 3.10 & 0.56 & 30.29 & 0.17 & 0.020 & 0.959 \\
\hline
\end{tabular}

Table 10: Distribution of cases according to fetal outcome in relation to $\mathrm{BMI}\left(\mathrm{kg} / \mathrm{m}^{2}\right)$.

\begin{tabular}{|c|c|c|c|c|c|c|c|c|c|c|c|}
\hline \multirow{3}{*}{ Fetal outcome } & \multirow{3}{*}{ Total } & \multicolumn{8}{|c|}{ BMI Group $\left(\mathrm{kg} / \mathrm{m}^{2}\right)$ first time presentation } & \multirow{3}{*}{$\chi^{2}$} & \multirow{3}{*}{$\mathbf{P}$} \\
\hline & & \multicolumn{2}{|c|}{$\begin{array}{l}\leq 18.5 \\
(n=26)\end{array}$} & \multicolumn{2}{|c|}{$\begin{array}{l}18.51-24.99 \\
(n=98)\end{array}$} & \multicolumn{2}{|c|}{$\begin{array}{l}25.00-29.00 \\
(n=15)\end{array}$} & \multicolumn{2}{|c|}{$\geq 30(n=9)$} & & \\
\hline & & No. & $\%$ & No. & $\%$ & No. & $\%$ & No. & $\%$ & & \\
\hline Macrosomia & 7 & 0 & - & 3 & 3.1 & 2 & 13.3 & 2 & 22.2 & 10.472 & 0.015 \\
\hline Fetal distress & 15 & 2 & 7.7 & 7 & 7.1 & 5 & 33.3 & 1 & 11.1 & 10.006 & 0.019 \\
\hline Convulsion & 4 & 1 & 3.8 & 2 & 2.0 & 1 & 6.7 & 0 & - & 1.439 & 0.696 \\
\hline $\begin{array}{l}\text { NICU } \\
\text { admission }\end{array}$ & 18 & 5 & 19.2 & 6 & 6.1 & 4 & 26.7 & 3 & 33.3 & 11.292 & 0.010 \\
\hline
\end{tabular}

Fetal distress was present in 15 cases and out of them 2, 7, 5 and 1 cases belonged to BMI grade I, II, III and IV respectively and this difference also found statistically significant difference $(\mathrm{p}<0.05)$. Only 4 cases had 
convulsion and out of them 1, 2 and 1 belonged to BMI grade I, II and III respectively and the difference was found statistically insignificant $(p>005)$ while NICU admission required in total 18 cases and out of them 5,6 ,
4 and 3 cases belonged to BMI grade I, II, III and IV respectively and this difference also had a significant change $(\mathrm{p}<0.05)$.

Table 11: Distribution of cases according to fetal outcome (at birth and within 7 days) in relation to $\mathrm{BMI}\left(\mathrm{kg} / \mathrm{m}^{2}\right)$.

\begin{tabular}{|c|c|c|c|c|c|c|c|c|c|c|c|}
\hline \multirow{3}{*}{ Fetal outcome } & & \multicolumn{8}{|c|}{ BMI Group $\left(\mathrm{kg} / \mathrm{m}^{2}\right)$ first time presentation } & \multirow{3}{*}{$\chi^{2}$} & \multirow{3}{*}{$\mathbf{P}$} \\
\hline & & \multicolumn{2}{|c|}{$\leq \mathbf{1 8 . 5}$} & \multicolumn{2}{|c|}{ 18.51-24.99 } & \multicolumn{2}{|c|}{ 25.00-29.00 } & \multicolumn{2}{|l|}{$\geq \mathbf{3 0}$} & & \\
\hline & & $\overline{\text { No. }}$ & $\%$ & No. & $\%$ & No. & $\%$ & $\overline{N o}$. & $\%$ & & \\
\hline \multirow[b]{2}{*}{ At Birth } & IUD & 1 & 3.8 & 0 & - & 1 & 6.7 & 0 & - & \multirow[b]{2}{*}{10.635} & \multirow[b]{2}{*}{0.100} \\
\hline & $\begin{array}{l}\text { Still } \\
\text { Birth }\end{array}$ & 1 & 3.8 & 0 & - & 0 & - & 0 & - & & \\
\hline Within 7 Days & Death & 0 & - & 0 & - & 0 & - & 1 & 11.1 & 15.550 & 0.001 \\
\hline
\end{tabular}

Table 12: Correlation of BMI with different parameters.

\begin{tabular}{|lll|}
\hline Parameters & $\begin{array}{l}\text { Correlation (r } \\
\text { value) }\end{array}$ & $\begin{array}{l}\text { Significance } \\
\text { value) }\end{array}$ \\
\hline Age & 0.431 & $<0.001$ \\
\hline $\begin{array}{l}\text { First trimester } \\
\text { BMI }\end{array}$ & 0.985 & $<0.001$ \\
\hline $\begin{array}{l}\text { Second trimester } \\
\text { BMI }\end{array}$ & 0.965 & $<0.001$ \\
\hline $\begin{array}{l}\text { Third trimester } \\
\text { BMI }\end{array}$ & 0.963 & $<0.001$ \\
\hline $\begin{array}{l}\text { Follow UP within } \\
\text { 2 weeks BMI }\end{array}$ & 0.963 & $<0.001$ \\
\hline Baby weight & 0.641 & $<0.001$ \\
\hline $\begin{array}{l}\text { Apgar score at 5 } \\
\text { Min }\end{array}$ & 0.255 & 0.002 \\
\hline
\end{tabular}

Table 13: Logistic regression analysis of different parameters with BMI.

\begin{tabular}{lllll} 
Parameters & Coefficients & $\mathrm{SE}$ & $\mathrm{t}$ & $\mathrm{p}$ \\
\hline Age & 0.015 & 0.018 & 0.833 & 0.406 \\
$\begin{array}{l}\text { First } \\
\text { trimester } \\
\text { BMI }\end{array}$ & 0.798 & 0.063 & 12.682 & $<0.001$ \\
\hline $\begin{array}{l}\text { Second } \\
\text { trimester } \\
\text { BMI }\end{array}$ & 0.112 & 0.068 & 1.649 & 0.101 \\
\hline $\begin{array}{l}\text { Third } \\
\text { trimester }\end{array}$ & 0.226 & 0.117 & 1.927 & 0.056 \\
$\begin{array}{l}\text { BMI } \\
\begin{array}{l}\text { Follow UP } \\
\text { within 2 }\end{array}\end{array}$ & 0.251 & 0.103 & 2.428 & 0.016 \\
$\begin{array}{l}\text { weeks BMI } \\
\text { Baby weight }\end{array}$ & 0.099 & 0.101 & 0.976 & 0.33 \\
$\begin{array}{l}\text { Apgar Score } \\
\text { at 5 Min }\end{array}$ & 0.188 & 0.066 & 2.859 & 0.005 \\
\hline
\end{tabular}

According to fetal outcome, 1 patient each had IUD and Still Birth in BMI grade I while 1 case of BMI grade III had IUD and the difference was found statistically insignificant while within 7 days only 1 death was observed and it belonged to obese group $(\mathrm{p}=0.001)$.

According to Table 12, when we correlate BMI to different parameters all the parameters like age, first, second, third trimester, follow up BMI and baby birth weight had highly significant correlation $(p<0.001$ in all) while Apgar score at 5 minutes had significant correlation with BMI $(p<0.01)$.

When we apply logistic regression analysis on different parameters with BMI, only first trimester BMI had highly significant correlation $(\mathrm{p}<0.001)$ while Follow up BMI and Apgar score at 5 minutes had significant correlation $(\mathrm{p}<0.05)$ while all other parameters like Age, second and third trimester, and baby weight had insignificant correlation $(\mathrm{p}>0.05)$.

\section{DISCUSSION}

Obesity is one of the most common and most neglected public health problems in both developing and developed countries. Maternal nutritional status plays an important role in weight gain which influence fetal outcome. Maternal malnutrition is the most important underlying determinant factor for adverse maternal and fetal outcome. In this study out of 148 cases there were 98 $(66.2 \%)$ of patients were with normal BMI, $26(17.56 \%)$ patients were underweight, $15(10.13 \%)$ patients were overweight and $9(6.08 \%)$ patients were obese and Similar observations were found by Tharihalli et al, in which $15 \%$ cases were underweight, $68 \%$ were normal, $12 \%$ were overweight and $5 \%$ cases were obese. ${ }^{25}$

In present study, maximum number of cases $47.3 \%$ were housewives, $43.2 \%$ cases were laborer and $9.5 \%$ cases were sedentary. In present study, $3.4 \%$ cases had their socioeconomic status II, $35.8 \%, 37.8 \%$ and $23 \%$ patients had their socioeconomic status III, IV and V respectively. Similar results were observed by John et al where they found $0 \%, 2 \%, 30 \%, 36 \%$ and $32 \%$ patients in socioeconomic status I, II, III, IV and V respectively. ${ }^{26}$ 
In present study (11.1\%) $1 / 9$ cases and $(6.7 \%) 1 / 15$ cases had APH in BMI grades 'IV and III' respectively and was found statistically significant with $\mathrm{p}$ value less than 0.05 . PIH was present in total 10 cases and out of them 4/98 (4.1\%), 3/9 (33.3\%), 2/15 (13.3\%) and 1/26 (3.8\%) cases belonged to BMI grades II, IV, III and I respectively Anemia was present in total 51 cases and out of them $36 / 98(36.7 \%), 14 / 26(53.8 \%)$ and $1 / 15(6.7 \%)$ cases belonged to BMI grades II, I and III respectively, preterm delivery was present in total 5 cases and out of them $2 / 26$ $(7.7 \%), 2 / 98(2 \%)$ and $1 / 9(11.1 \%)$ belonged to BMI grades I, II and IV respectively. GDM was present in only 11 cases and out of them 4/15 (26.7\%), 4/9 (44.4\%) and $3 / 98(3.1 \%)$ cases belonged to BMI grade III, IV and II respectively. PPH was present in total 5 cases and out of them $2 / 26(7.7 \%), 2 / 98(2 \%)$ and $1 / 9(11.1 \%)$ belonged to BMI grades I, II and IV respectively other maternal outcome was present in 4 cases and out of them $3 / 98(3.1 \%)$ and $1 / 26(3.8 \%)$ belonged to BMI grade II and I respectively. APH, PIH, Anemia had significant relation $(p<0.05)$ while GDM and had highly significant difference $(\mathrm{p}<0.001)$ and preterm, PPH and other had insignificant difference $(\mathrm{p}>0.05)$.

Tharihalli and Thathagari in their study found similar observation. ${ }^{25}$ Out of total of 500 cases, the incidence of PIH was highest in obese group (28\%) and overweight group (25\%) compared to normal BMI group $(6.17 \%)$ and underweight group (2.6\%).

According to type of delivery, 21(80\%) cases of vaginal had their BMI underweight group and their mean birth weight was $1.44 \mathrm{~kg}, 67(68.36 \%)$ cases of vaginal delivery had their BMI within normal range and their mean birth weight was $2.77 \mathrm{~kg}, 5(33 \%)$ cases of vaginal delivery had their BMI within over weight range and their mean birth weight was $3.05 \mathrm{~kg}$ while only $1(1.1 \%)$ vaginal delivery had her BMI in obese group and the baby birth weight was $2.20 \mathrm{~kg}$. This shows that as BMI increases, baby birth weight also increases and also increased caesarean deliveries. There were $(88.8 \%)$ LSCS in obese patients, $(66.6 \%)$ in overweight $(31.6 \%)$ were in normal BMI, and $(19.2 \%)$ cases were in underweight.

According to Apgar score at 5 minutes, (30.8\%) and $(69.2 \%)$ cases of underweight group had their Apgar score $\leq 7$ and $>7$ respectively. In normal BMI group, $(13.2 \%)$ and $(86.7 \%)$ cases had their Apgar score $\leq 7$ and $>7$ respectively, in over weight group, (40\%) and (60\%) cases had their Apgar score $\leq 7$ and $>7$ respectively while in obese cases, $(11.1 \%)$ and $(88.9 \%)$ cases had their Apgar score $\leq 7$ and $>7$ respectively, the difference was found statistically significant $(\mathrm{p}<0.01)$.

According to fetal outcome, macrosomia was present in total 7 cases and out of them $2(22.2 \%)$ cases belonged to BMI grade IV and $3(3.1 \%)$ and 2 (13.3\%) cases belonged to BMI grade II and III respectively and the difference was found statistically significant $(p<0.05)$. Fetal distress was present in 15 cases and out of them 5
(33.3\%) cases belonged to BMI grade II, and 1 (11.1\%), $2(7.7 \%)$ and $7(7.1 \%)$ cases belong to BMI grade III, I, and IV respectively and this difference also found statistically significant difference $(p<0.05)$.

In present study, on applying logistic regression analysis on different parameters with BMI, only first trimester BMI had highly significant correlation $(\mathrm{p}<0.001)$ while Follow up BMI and APGAR score at 5 minutes had significant correlation $(\mathrm{p}<0.05)$ while all other parameters like Age, second and third trimester, and baby weight had insignificant correlation ( $\mathrm{p}>0.05)$.

\section{CONCLUSION}

Authors conclude that BMI plays major role in maternal and perinatal outcome and both low BMI and high BMI had significant maternal and perinatal outcome. We observed that as trimester advanced BMI is also increased. Patient in underweight cases or BMI grade I during antenatal suffered from Anemia, pre term delivery, IUGR, low birth weight baby these low apgar score. Fetus of underweight BMI group developed more jaundice with long NICU stay. In postpartum period underweight patient developed fever due to wound infections and mastitis. In overweight and obese cases or in BMI grade 3 and 4 also had maternal and fetal problems during antinatal period, durig labour and post partum period. Patients suffered from more complications like PIH, GDM, PROM, IUGR and PPH. We observed that BMI grade 3 and 4 cases higher number of patients developed diabetes and hypertension both these patients delivered a macrosomic babies. In overweight and obese patients mode of delivery was LSCS due to macrosomic baby, hypertension and IUGR.

In underweight cases IUD and stillbirth were noted but it was statistically insignificant with BMI grade.

Authors conclude that there is in presence of pregnancy counseling in maintaining weight of women during pregnancy to avoid pregnancy complication and both maternal and fetal outcome.

Funding: No funding sources

Conflict of interest: None declared

Ethical approval: The study was approved by the Institutional Ethics Committee

\section{REFERENCES}

1. Park K. Park's Textbook of Preventive and Social Medicine. 24 ${ }^{\text {th }}$ ed. Banarasidas Bhanot;2015:397.

2. Kim SY, Dietz PM, England L, Morrow B, Callaghan WM. Trends in pre-pregnancy obesity in nine states 1993-2003. Obesity 2007;15:986-93.

3. Frederick IO, Williams MA, Sales AE, Martin DP, Killien M. Prepregnancy body mass index, gestational weight gain, and other maternal 
characteristics in relation to infant birth weight. Maternal Child Health J. 2008;12:557-67.

4. Mohan V, Deepa R. Obesity and abdominal obesity in Asian Indians. Indian J Med Res. 2006;123:593-6.

5. Bhardwaj S, Misra A, Misra R, Goel K, Bhatt SP, Rastogi KV, et al. High prevalence of abdominal, intra-abdominal and subcutaneous adiposity and clustering of risk factors among urban Asian Indians in North India. PLoS One. 2011;6:e24362.

6. Deepa M, Farooq S, Deepa R, Manjula D, Mohan V. Prevalence and significance of generalized and central body obesity in an urban Asian Indian population in Chennai, India (CURES: 47) Eur J Clin Nutr. 2009;63:259-67.

7. Misra A, Khurana L. Obesity and the metabolic syndrome in developing countries. J Clin Endocrinol Metab. 2008;93(11 Suppl 1):S9-30.

8. Mendez MA, Monteiro CA, Popkin BM. Overweight exceeds underweight among women in most developing countries. Am J Clin Nutr. 2005;81:71421.

9. Balarajan Y, Villamor E. Nationally representative surveys show recent increases in the prevalence of overweight and obesity among women of reproductive age in Bangladesh, Nepal, and India. J Nutr. 2009;139:2139-44.

10. Riz AM, Laraia B. The implications of maternal overweight and obesity on the course of pregnancy and birth outcomes. Matern Child Health J. 2006;10(5):153-6.

11. Andreasen KR, Andersen ML, Schantz AL. Obesity and pregnancy. Acta Obstet Gynecol Scand. 2004;83(11):1022-9.

12. Guelinckx I, Devlieger R, Beckers K, Vansant G. Maternal obesity: pregnancy complications, gestational weight gain and nutrition. Obes Rev. 2008; 9(2):140-50.

13. Heslehurst N, Simpson H, Ells LJ, Rankin J, Wilkinson J, Lang R, et al. The impact of maternal BMI status on pregnancy outcomes with immediate short-term obstetric resource implications: a metaanalysis. Obes Rev. 2008;9(6):635-83.

14. Ehrenberg H, Mercer B, Catalano P. The influence of obesity and diabetes on the prevalence of macrosomia. Am J Obstet Gynecol. 2004;191:964-8.

15. Doherty DA, Magann EF, Francis J, Morrison JC, Newnham JP. Prepregnancy body mass index and pregnancy outcomes. Int $\mathbf{J}$ Gynae Obst. 2006;95(3):242-7.
16. Callaway LK, Prins JB, Chang AM, McIntyre HD:The prevalence and impact of overweight and obesity in an Australian obstetric population. Med J Australia. 2006;184(2):56-9.

17. Sahu MT, Agarwal A, Das V, Pandey A. Impact of maternal body mass index on obstetric outcome. J Obstet Gynaecol Res. 2007;33(5):655-9.

18. Abenhaim HA, Kinch RA, Morin L, Benjamin A, Usher R. Effect of prepregnancy body mass index categories on obstetrical and neonatal outcomes. Arch Gynecol Obstet. 2007;275(1):39-43.

19. John J, Mahendran M. Maternal and fetal outcomes of obese pregnant women: a prospective cohort study. Int J Reprod Contracept Obstet Gynecol. 2017;6(2):725-9.

20. Tharihalli C, Thathagari V. Study of correlation between maternal body mass index with maternal and perinatal outcome. Int $\mathbf{J}$ Reprod Contracept Obstet Gynecol. 2017;6(1):164-7.

21. RCOG, 5th October 2006 Press Releases Available at http://rcog.org.uk/index.asp? pageID=97 \& Press ReleaseID $=126$.

22. Tharihalli C, Thathagari V. Study of correlation between maternal body mass index with maternal and perinatal outcome. Int $\mathbf{J}$ Reprod Contracept Obstet Gynecol. 2017;6(1):164-7.

23. Frederick IO, Rudra CB, Miller RS, Foster JC, Williams MA. Adult weight change, weight cycling, and prepregnancy obesity in relation to risk of preeclampsia. Epidemiology 2006;17:428-34.

24. Cedergren M. Effects of gestational weight gain and body mass index on obstetric outcome in Sweden. Int J Gynaecol Obstet. 2006;93(3):269-74.

25. Tharihalli C, Thathagari V. Study of correlation between maternal body mass index with maternal and perinatal outcome. Int $\mathrm{J}$ Reprod Contracept Obstet Gynecol. 2017; 6(1):164-7.

26. John J, Mahendran M. Maternal and fetal outcomes of obese pregnant women: a prospective cohort study. Int J Reprod Contracept Obstet Gynecol. 2017;6(2):725-9.

Cite this article as: Choudhary J, Singh S, Tiwari K. Study of BMI in pregnancy and its correlation with maternal and perinatal outcome. Int J Reprod Contracept Obstet Gynecol 2018;7:2472-9. 